\title{
A Temnospondyl Amphibian from the Rio do Rasto Formation, Upper Permian of Southern Brazil
}

\author{
ELISEU V. DIAS ${ }^{1,2}$ and MARIO C. BARBERENA ${ }^{1}$ \\ ${ }^{1}$ Universidade Federal do Rio Grande do Sul, Instituto de Geociências - PG \\ 91509-900 Porto Alegre, RS, Brasil. \\ ${ }^{2}$ Universidade Regional Integrada do Alto Uruguai e das Missões, \\ Campus de Erechim, Departamento de Ciências Biológicas, 99700-000 Erechim, RS, Brasil. \\ Manuscript received on February 11, 2000; accepted for publication on October 20, 2000; \\ contributed by MÁRIO C. BARBERENA*
}

\begin{abstract}
A partially preserved lower jaw constitutes the holotype of Bageherpeton longignathus $\mathrm{n}$. g., $\mathrm{n}$. sp., a probable archegosaurid amphibian, which is here assigned to the Platyoposaurinae. The material was collected in the beds of the Rio do Rasto Formation outcropping in Rio Grande do Sul State, southern Brazil. This is the second archegosaurid described for the Permian of Brazil. Prionosuchus plummeri Price 1948, from the Pedra do Fogo Formation in the Parnaiba Basin (northeastern Brazil), is the first. The new taxon differs from other platyoposaurs by the presence of an extremely elongated precoronoid that participates in the mandibular symphysis.
\end{abstract}

Key words: Amphibia, Temnospondyli, Archegosauridae, Platyoposaurinae, Rio do Rasto Formation, Late Permian.

\section{INTRODUCTION}

The Permian-Triassic sequence of southern Brazil has a significant fossil vertebrate record. The occurrence of fossil amphibians is, at the moment, restricted to the Rio do Rasto and Sanga do Cabral Formations. The Rio do Rasto Formation, that belongs to the Passa Dois Group and is dated as Late Permian based on tetrapod faunas (Barberena et al. 1980, 1985, 1991), has an extensive area of outcrops which extends from Paraná State to the Rio Grande do Sul State, comprising a belt of more than a thousand kilometers long (Fig. 1). The Sanga do Cabral Formation, of Scythian age, is restricted to the cen-

\footnotetext{
* Member of Academia Brasileira de Ciências Correspondence to: Eliseu Vieira Dias E-mail: evdias@if.ufrgs.br
}

tral area of Rio Grande do Sul State (Barberena et al. 1985, 1991, Dias-da-Silva 1999, Dias-da-Silva \& Schultz 1999a, b).

Two distinct faunas of the Rio do Rasto Formation can be identified in two different levels. In outcrops of the Paraná State (lower level) was recorded the presence of Endothiodon (Barberena et al. 1985) and a Rhinesuchus-like amphibian (Barberena \& Dias 1998), as well as Australerpeton cosgriffi, a long-snouted rhinesuchoid amphibian (Barberena 1998) and fossil fishes (Ragonha 1989, Dias 1996). On the other hand, in outcrops of the Rio Grande do Sul State, comprising the upper levels of this formation, occur fish remains (Würdig-Maciel 1975, Richter et al. 1985), Pareiasaurus americanus (Barberena et al. 1985) and the material described 


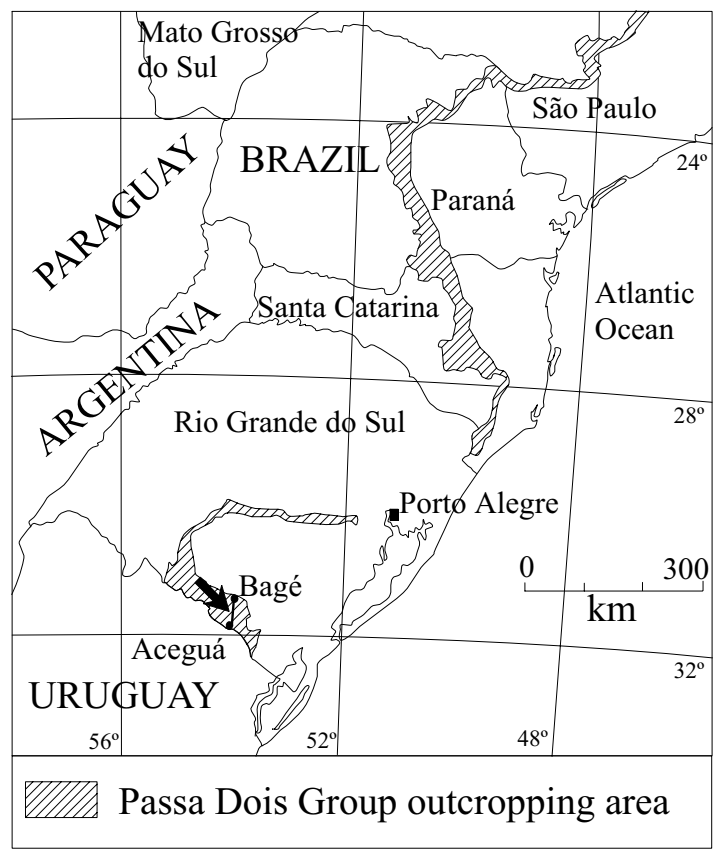

Fig. 1 - The sedimentary belt of the Passa Dois Group, including the Rio do Rasto Formation, along the São Paulo, Paraná, Santa Catarina e Rio Grande do Sul States in southern Brazil. Arrow indicates the Bagé-Aceguá Road, along which (km 176) lies the outcrop where Bageherpeton longignathus was collected.

here. These two levels have been tentatively correlated with the Upper Permian South African tetrapod zones, Cistecephalus and Daptocephalus, respectively, following Kitching (1977). In this point of view, the age of the Rio do Rasto Formation is corroborated by the Upper Permian distribution of rhinesuchid amphibians and also by the presence of other Upper Permian tetrapods such as Pareiasaurus and Endothiodon.

The Pareiasaurus americanus described by Araújo (1985a, b, 1986a, b) and Araújo-Barberena (1987, 1989a, b) was considered to belong to Provelosaurus americanus (Lee 1997), a sister group of the South African dwarf-pareiasaurs, such as $A n$ thodon, that are known from Cistecephalus and $\mathrm{Di}$ cynodon tetrapod assemblage Zones in the Karoo (Rubidge et al. 1995). Langer (2000) has described a dinocephalian fauna of the Rio do Rasto Forma- tion, correlated to the Eodicynodon and Tapinocephalus Assemblage Zones, a probably third and much lower level.

The material described here is a new occurrence for the Rio do Rasto Formation upper levels and it was collected at $\mathrm{Km} 176$ on the BR 153 road, between Bagé and Aceguá cities, Rio Grande do Sul State. It is the archegosaurid temnospondyl discussed by Langer (2000) and it was found associated with isolated scales of paleoniscoid fishes studied by Würdig-Maciel (1975) and Richter et al. (1985).

It is a partially preserved lower jaw of a long-snouted amphibian, whose morphology, as discussed bellow, indicates the presence of a new taxon. It is now housed at the Institute of Geosciences of the Federal University of Rio Grande do Sul under the collection number (UFRGS -PV-0317-P).

\section{SYSTEMATIC PALEONTOLOGY}

Amphibia sensu Milner 1993

'Temnospondyli' sensu Milner 1993

Archegosauroidea sensu Gubin 1997

Archegosauridae sensu Gubin 1991

Platyoposaurinae sensu Gubin 1991

Bageherpeton longignathus $\mathrm{n}$. g., $\mathrm{n}$. sp.

Generic name - Bageherpeton derives from the name of the Bagé city and herpeton, from Greek language meaning, animal that moves crawling.

Specific name $-B$. longignathus in relation to the elongated lower jaw, from the Latin, long $i=$ long and from the Greek, gnathus = jaw.

Holotype - an incomplete lower jaw (UFRGS PV0317-P) housed in the collection of the Institute of Geosciences (Federal University of Rio Grande do Sul), Brazil.

Type locality - Km 176 of the BR 153 road, between the cities of Bagé and Aceguá, Rio Grande do Sul State, Brazil. 
Stratigraphic horizon - upper levels of the Rio do Rasto Formation, Late Permian.

Diagnosis - a long-snouted labyrinthodont amphibian with a remarkably extended symphysis. Precoronoid elongated and participating in the symphysis. Lingual surface elevated from the teeth base level as a longitudinal bar-like structure.

\section{DESCRIPTION}

The specimen consists of the middle portion of a lower jaw, with a preserved length of $32 \mathrm{~cm}$ (Fig. 2, A, B, C, D).

In lingual (or dorsal) view, the dentary extends along the lateral margin of the preserved segment of the lower jaw. The labirynthodont condition can be seen in some teeth transversally broken. There are 13 robust tusk-like teeth preserved at the left side and 14 at the right. Most of them are straight, but some are posteriorly curved. Scars of lost teeth occur on both sides of the jaw, 10 at the right and 12 at the left. These scars are almost circular and concave-shaped (Fig. 2 and Fig. 3).

The saggital suture between the dentaries is visible in the anterior quarter of the jaw. Posteriorly, in the other three-quarters, the suture is formed not only by the dentary and splenials, but also by the coronoid series, what is a somewhat surprising condition. (Fig. $3 \mathrm{~A}, \mathrm{~B}$; pc). The precoronoids are the most elongate, comprising almost two quarters of the saggital suture. The intercoronoids appear in the last quarter as narrowly elongate wedge-shaped bones, laterally to the precoronoids.

The posterior end of the suture is formed by the splenials, also wedge-shaped and interposed between the precoronoids. Their anterior tip lies shortly behind the anterior extremity of intercoronoids. Posteriorly splenials and precoronoids form, respectively, the medial and lateral borders of a pair of well-marked concavities, here interpreted as probable sites for the fitting of the vomerine tusks during occlusion (Fig. 2, C,E; Fig 3 B; Fig 4 C). Splenials can also be seen in a area which lies on the limits between the first and second quarters of the jaw in lingual view, where they appear as a small bone fillet, between the anterior tip of the precoronoids and the medial border of the dentary (Fig. 3B).

In the ventral view of the jaw, the dentary bone is identified as forming the totality of its lateral margin. The saggital suture is defined by the dentaries in the anteriormost quarter; in the posterior three quarters it is assumed by the long tapering splenials (Fig. 2 D; Fig. 3 C).

The conspicuous bar-like structure already mentioned as existing along the anterior three quarters of the lingual surface of the lower jaw might have served as an important device to strengthen the long mandibular symphysis. The height of this bar reaches a maximum at the middle point of the preserved jaw segment and diminishes posteriorly to become a depressed area at the posterior quarter, just in front of the concavities for the vomerine tusks (Fig. 2; Fig. 3 A, B; Fig. 4 A-C). The presence of some very worn down small denticles on the precoronoids seems to suggest that the bar-like structure could also help in obtaining a better gripping of the food inside the oral cavity.

Observation of the specimen from its posterior end reveals the existence of two large apertures, bilaterally disposed and filled by sediment, which very probably indicate the space for the Meckelian cartilages (Fig. 2 E). Figure 4 (C) represents these cavities in a reconstructed transversal section.

Interestingly enough, Bageherpeton longignathus does not present any evidence of sensorial canals on the dentary surface in both sides of the specimen.

\section{DISCUSSION}

Long-snouted amphibian lineages have developed in at least three independent groups of Temnospondyli: the archegosaurians, trematosaurians (Milner \& Sequeira 1997) and rhinesuchoideans (Barberena 1998). In these groups, the mandibular symphysis is variable from a restrict anterior portion 


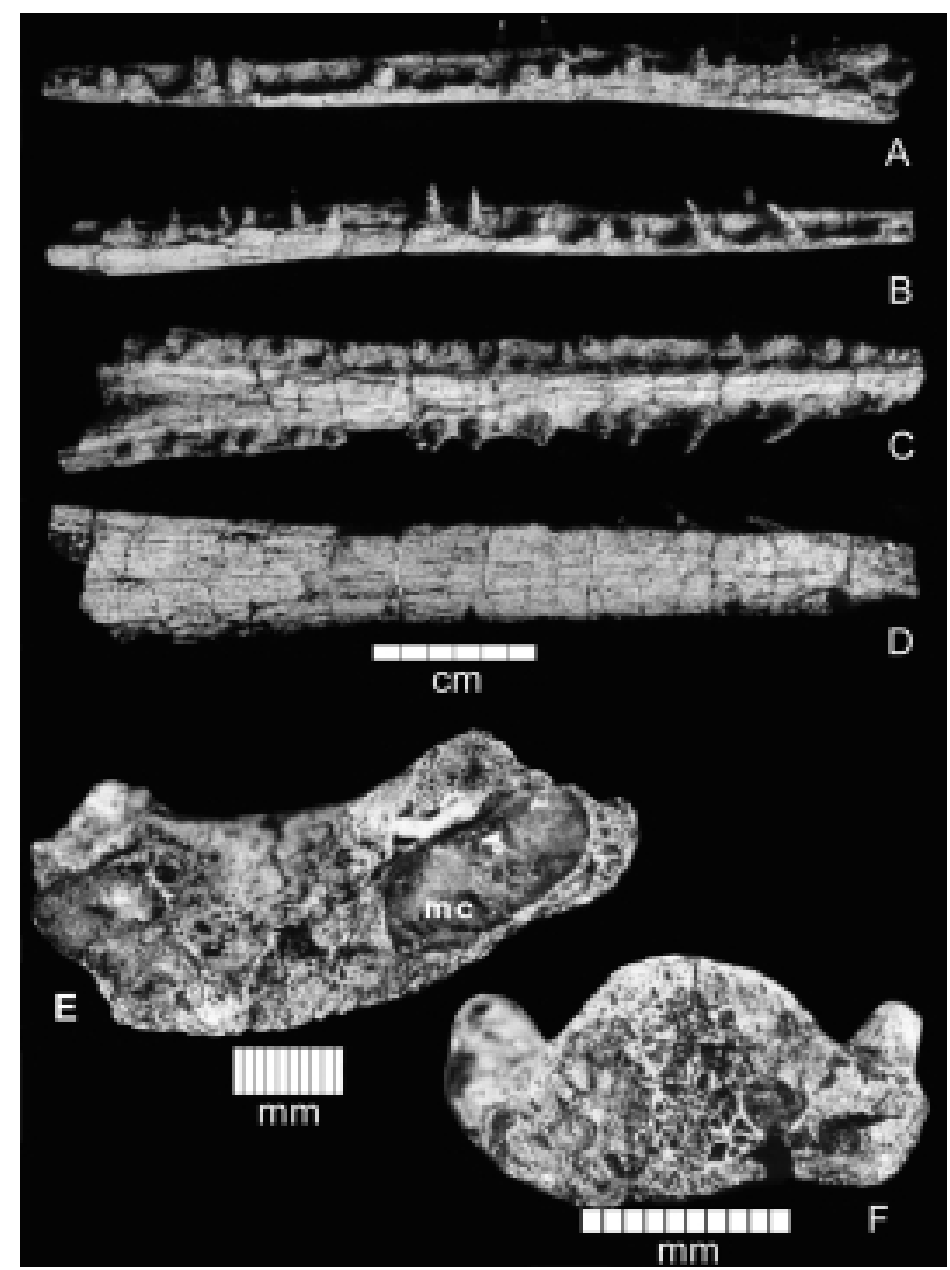

Fig. 2 - Photography of Bageherpeton longignathus holotype. Lateral view of the left side (A) and right side (B); lingual view (C), ventral view (D), posterior view $(\mathrm{E})$ and anterior view $(\mathrm{F})$.

to an elongated symphysis, normally in correlation to the cranial shape. Short-snouted amphibians normally have a short symphysis and long- snouted ones tend to develop an elongated symphysis.

In archegosaurians, this feature is variable. In Archegosaurus dechini (Gubin 1997), the young form is short-snouted and the adult has a slightly elongated snout, but its symphysis retains the young condition. Other long-snouted archegosaurians have an elongated symphysis, such as Platyoposaurus, Baschkirosaurus and Prionosuchus plummeri. Gubin (1997) uses the long symphysis of the lower jaw as one of the characters of the node 8 of his cladogram, which defines Platyoposaurus and Baschkirosaurus as sister groups within the archegosauroids, but mentioned the occurrence of this character in other groups as an independent developed structure.

In the elongated symphysis of Platyoposaurus stuckenbergi Konzhukova (1955), the precoronoid and intercoronoid bones participate of the suture (Gubin 1991). The contact between precoronoid and 


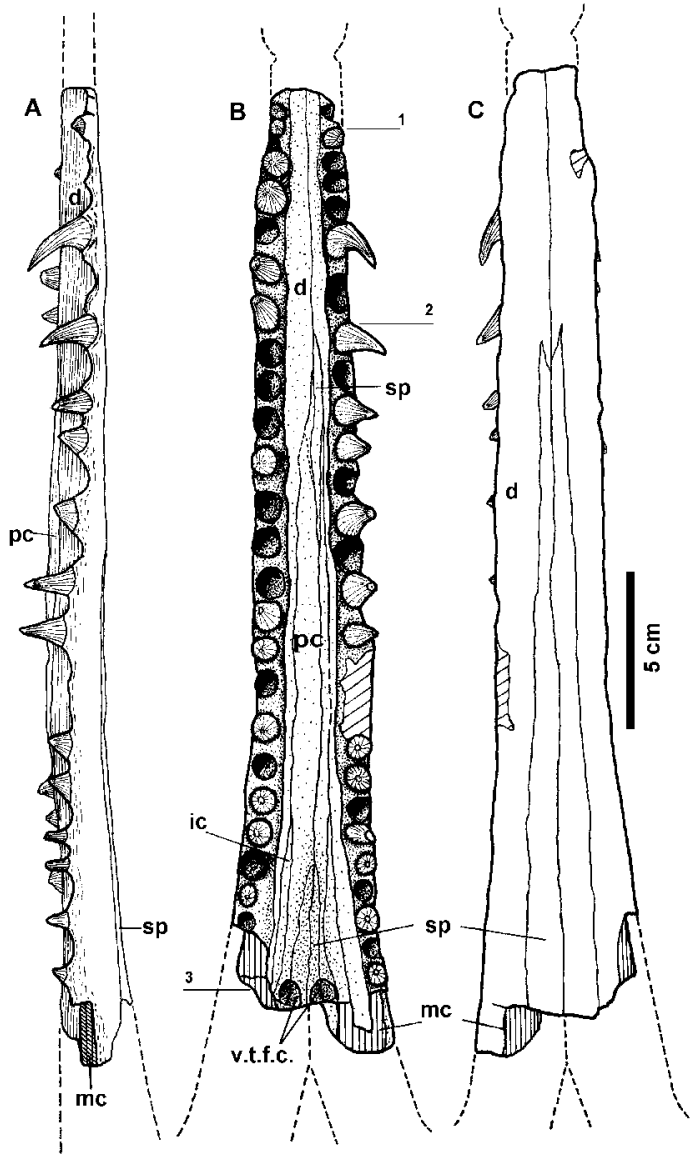

Fig. 3 - Drawing of the Bageherpeton longignathus; (A) lateral view of the right side; (B) lingual view; (C) ventral view. The numbered lines indicates the aproximated position of the cross sections presented in the figure $4 . \mathrm{d}=$ dentary; ic = intercoronoid; $\mathrm{mc}=$ meckelian cavity $; \mathrm{pc}=$ precoronoid $; \mathrm{sp}=$ splenial; v.t.f.c. $=$ vomerine tusk fitting cavity.

intercoronoid is perpendicular to the symphysis. Both bones are not so elongated in Platyoposaurus stuckenbergi as they are in Bageherpeton longignathus and a parasaggital suture between them is present only in the second (Fig 2, b; Fig. 3, b). The dentary teeth of Platyoposaurus stuckenbergi at the middle portion of symphysis seem to be smaller than in Bageherpeton longignathus. P. stuckenbergi also does not present the elevation of the lingual surface as the bar-like structure that is clear in $B$. longignathus.
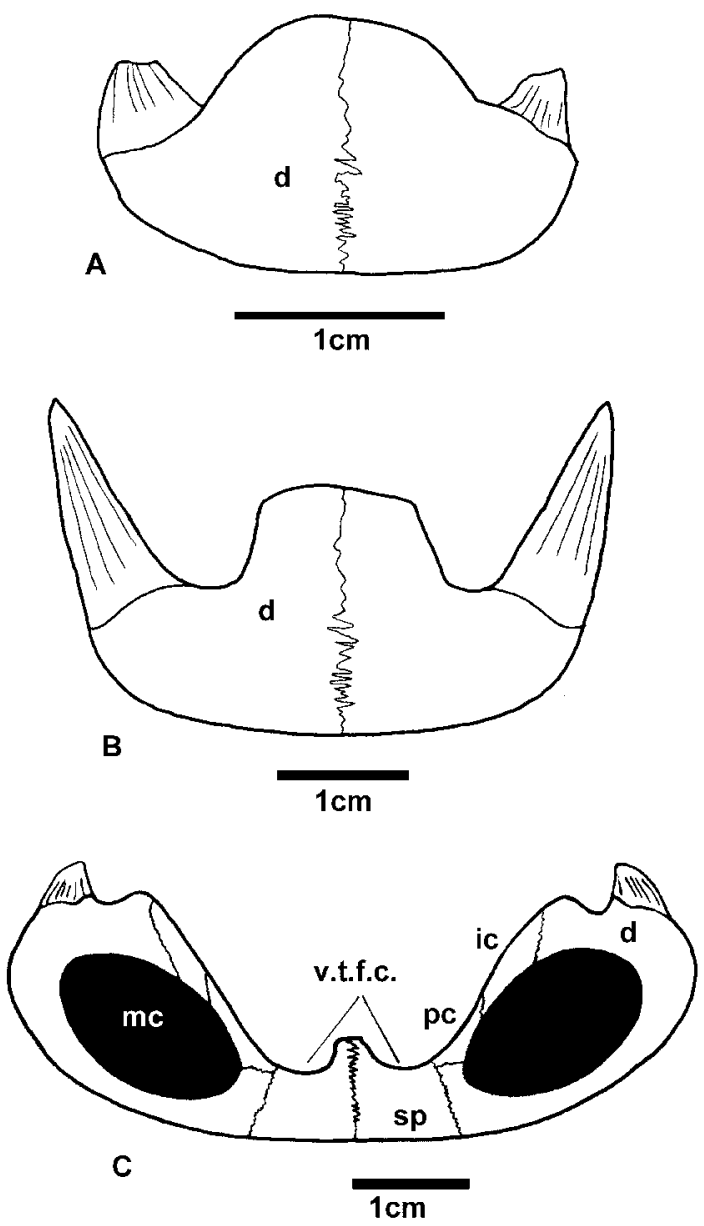

Fig. 4 - Drawings of hypothetical cross sections of the Bageherpeton longignathus; (A) anterior; (B) median; (C) posterior portion. $\mathrm{d}=$ dentary; ic $=$ intercoronoid; $\mathrm{mc}=$ meckelian cavity; $\mathrm{pc}=$ precoronoid $\mathrm{sp}=$ splenial; v.t.f.c. $=$ vomerine tusk fitting cavity.

In the original description of Prionosuchus plummeri, Price (1948) mentioned that the preserved portion of the lower jaw presents, in ventral view, a symphysis composed by the splenials, and "the lingual surface of the dentary shows a typical sutural surface indicating that a coronoid extended anterior to the posterior limits of the symphysial suture". Unfortunately, the preserved lower jaw portion of $P$. plummeri can not provide precise information for comparisons. The lower jaw symphysis of Bageherpeton longignathus was as elongated as the one 
presumed for Prionosuchus plummeri and also exhibits the participation of the coronoid in the symphysial area.

Bageherpeton longignathus has the anterior portion of the lower jaw convex and bar-like shaped. According to the illustrations of Price (1948), Barberena (1972) and Cox and Hutchinson (1991), the palate of Prionosuchus plummeri is also convex. If we addmited the same convexity for the palate of Bageherpeton, a operational occlusion would be difficult. When the two convex surfaces touch one another, the teeth would not penetrate completely in the prey. So we believe that the palate of Bageherpeton should be concave or at least in the same plan of the teeth bases. This feature also indicates that the lower jaw described as B. longignathus does not belong to Prionosuchus plummeri.

The material assigned to Platyops (Platyoposaurus) occurring in the Rio do Rasto Formation (Barberena \& Daemon 1974) is now known as the rhinesuchoid Australerpeton cosgriffi Barberena 1998, another long-snout amphibian from Rio do Rasto Formation. It also has an elongated lower jaw, but its symphysis is slender and less elongated than that of Bageherpeton longignathus and there are no evidence of the bar-like convex structure. The poor preservation of Australerpeton lower jaw remains does not inform on the participation of the coronoid series in the symphysis (Dias \& Barberena in prep.). Bageherpeton longignathus is different from Australerpeton cosgriffi because of the stronger lower jaw symphysis in the first and the absence of the bar-like structure in the second.

Other long-snouted amphibians are the trematosaurians. Welles (1993) has divided them into two groups: Trematosaurinae - with a short dentary symphysis; and Lonchorhynchinae - with a very long one. Unfortunately, we have not found detailed descriptions of the symphysial area and coronoid series in the Lonchorhynchinae trematosaurians.

Though detailed morphological configurations of the symphysial area in trematosaurians is not available in the consulted literature, the exclusive presence of trematosaurians in Triassic sediments indicates that $B$. longignathus could not be assigned to them. For this assertion we follow the trematosaurians range of Milner (1993), that is from the Lower to Upper Triassic.

In spite of the limitations discussed above, Bageherpeton longignathus is tentatively classified as an platyoposaurid archegosaurian.

The vomerine teeth fitting cavities, the bar-like convex shaped lingual surface and the elongation of the intercoronoid and precoronoid with a parasaggital suture between them seem to be peculiar and properly considered as apomorphies for Bageherpeton longignathus.

\section{CONCLUDING REMARKS}

Werneburg and Schneider (1996) suggested that archegosaurians could have had a large distribution not only in Laurasia but also throughout Gondwana. This is confirmed by the presence of Prionosuchus plummeri and Bageherpeton longignathus in two distinct deposits from the Permian of Gondwana.

Following Milner (1990) and Milner (1993), the archegosaurians temporal distribution spans from the Lower Permian (Asselian/Sakmarian) to the Lower Tatarian. Cox and Hutchinson (1991), using the rostrum length as a reliable character, established evolutionary stages for archegosaurians; by means of this inference they suggested that the Pedra do Fogo Formation is of Late Permian age. Nevertheless, they did not consider all other fossil evidences, such as plants and pollens, which indicate an Early Permian age (Mussa \& Coimbra 1987, Caldas et al. 1989).

Ontogenetical variations of some archegosaurians, such as Collidosuchus tchudinovi (Gubin 1986 apud Werneburg \& Schneider 1996), show distinct rostrum lengths and shapes throughout their life. This evidence points out that the evolutionary stages of the archegosaurians, as indicated by the proportional length of the rostrum, do not seem to be a satisfactory argument for this change in age from Early to Late Permian. 
If we assume the age suggested by Cox and Hutchinson (1991) for the Pedra do Fogo Formation, Prionosuchus plummeri and Bageherpeton longignathus have to be of approximated age, both from Upper Permian. On the other hand, by following Mussa and Coimbra (1987) in considering the Pedra do Fogo of Early Permian age, Bageherpeton longignathus rends to be much latter than Prionosuchus plummeri.

In this second point of view, the archegosaurians arrived in South America coming from Laurasia and lived initially (Early Permian) in the north of South America (Pedra do Fogo Formation). During the Permian age, as the Gondwana drift to north, the archegosaurians arrived in southern lands in the Late Permian (Rio do Rasto Formation), following the environment displacement. The fossil association of Provelosaurus and Bageherpeton in the upper levels of the Rio do Rasto Formation can indicate that the archegosaurians could reach the Late Tatarian.

The symphysial morphology indicates that Bageherpeton longignathus was mainly a fish eater. The bar-like shape of the lingual surface of the lower jaw could be a reinforcement for catching fishes and also to immobilize and smash them during occlusion. The remains of worn down denticles in the precoronoid could indicate their effective auxiliary role for the smashing of the prey during occlusion. The occurrence of isolated paleoniscoid fish scales in association with this temnospondyl indicates their presence in the environment, making possible a piscivore diet.

\section{ACKNOWLEDGEMENTS}

We thank to Dr. Ernesto L. C. Lavina for important informations related to his stratigraphical work on the Late Permian sediments of southern Brazil and Drs. Andrew Milner, Ralf Werneburg and Yuri Gubin for the sending of significant literature concerning the archegosaurian amphibians. Thanks are also due to Mrs. Cristina Vega Dias for the language review of this paper, to Mr. Luiz Flávio Pereira
Lopes for the photographic work, Mr. Juan Carlos Cisneros for the drawings and Dr. José Eduardo Figueiredo Dornelles for the improvement in the figure $3 \mathrm{a}$.

\section{RESUMO}

Uma mandíbula parcialmente preservada constitui o holótipo de Bageherpeton longignathus n. g., n. sp., um provável anfíbio arquegossaurídeo aqui considerado como um Platyoposaurinae. O material foi coletado nas camadas da Formação Rio do Rasto que afloram no Estado do Rio Grande do Sul, no sul do Brasil. Este é o segundo arquegossaurídeo descrito para o Permiano do Brasil. O primeiro é Prionosuchus plummeri Price 1948, da Formação Pedra de Fogo na Bacia do Parnaíba (nordeste do Brasil). O novo taxon difere dos outros platiopossauros pela presença de um pre-coronóide extremamente longo que participa da sínfise mandibular.

Palavras-chave: Amphibia, Temnospondyli, Archegosauridae, Platyoposaurinae, Formação Rio do Rasto, Permiano Superior.

\section{REFERENCES}

Araújo DC. 1985a. Sobre Pareiasaurus americanus sp. nov., do Permiano-Superior do Rio Grande do Sul, Brasil. I - Diagnose específica. An Acad Bras Ci 57: 63-66.

ARAúJo DC. 1985b. Estudo do material sul-americano de Pareiasauroidea. II - Descrição osteológica do crânio de Pareiasaurus americanus. An Acad Bras Ci 58: 67-85.

ARAúJo DC. 1986a. Estudo do material sul-americano de Pareiasauroidea. III - Descrição osteológica da escápula-coracóide de Pareiasaurus americanus. An Acad Bras Ci 58: 381-387.

ARAúJo DC. 1986b. Estudo do material sul-americano de Pareiasauroidea. IV - Descrição ostelógica do propódio e epipódio dos membros anterior e posterior de Pareiasaurus americanus. An Acad Bras Ci 58: 389403.

Araújo-Barberena DC. 1987. Armadura osteodérmica de Pareiasaurus americanus Araújo 1985 (Coty- 
losauria, Procolophonia, Pareiasauroidea) do Permiano Superior do Rio Grande do Sul, Brasil. PaulaCoutiana 1: 11-16.

Araújo-Barberena DC. 1989a. Estudo do material sulamericano de Pareiasauroidea. V. Descrição da pelvis de Pareiasaurus americanus Araújo 1985. An Acad Bras Ci 61: 285-294.

Araújo-BARberena DC. 1989b. Estudo do material sul-americano de Pareiasauroidea. VI. Descrição do esqueleto axial de Pareiasaurus americanus Araújo 1985. An Acad Bras Ci 61: 285-294.

Barberena MC. 1972. South American Late Paleozoic tetrapods. An Acad Bras Ci 44(supl.): 67-75.

BARberena MC. 1998. Australerpeton cosgriffi n.g., n.sp., a Late Permian Rhinesuchoid amphibian from Brazil. An Acad Bras Ci 70: 125-137.

BARBERENA MC \& DAEMON RF. 1974. A primeira ocorrência de Amphibia (Labyrinthodontia) na Formação Rio do Rasto; implicações geocronológicas e estratigráficas. $28^{\circ}$ CONGRESSO BRASILEIRO DE GEOLOGIA. São Paulo, Brazil. Anais ..., 2: 251-261.

Barberena MC \& Dias EV. 1998. On the presence of a short-snouted rhinesuchoid amphibian in the Rio do Rasto Formation (Late Permian of Paraná Basin, Brazil). An Acad Bras Ci 70: 465-468.

Barberena MC, Correia NR \& Aumound JJ. 1980. Contribuição à estratigrafia e bioestratigrafia do Grupo Passa Dois na Serra do Cadeado (Nordeste do Paraná, Brasil). Rev Bras Geoc 10: 268-275.

Barberena MC, Araújo DC \& Lavina EL. 1985. Late Permian and Triassic tetrapods of Southern Brazil. National Geographic Research 1: 5-20.

Barberena MC, Araújo-Barberena DC, Lavina EL \& FACCINI UF. 1991. The evidence for close paleofaunistic affinity between South America and Africa, as indicated by Late Permian and Early Triassic Tetrapods. 7th International Gondwana Symposium, São Paulo. Proceedings..., São Paulo: p.455-467.

Caldas EB, Mussa D, Lima Filho FP \& Roesler O. 1989. Nota sobre a ocorrência de uma floresta petrificada de idade permiana em Teresina, Piauí. Bol
IG-USP, Publ Esp 7: 69-87.

Cox CB \& Hutchinson P. 1991. Fishes and amphibians from the Late Permian Pedra do Fogo Formation of Northern Brazil. Palaeontology 34: 561-573.

Dias EV. 1996. New fish (Actinopterygii, Platysomidae) from the Upper Permian of Parana Basin, Brazil. Ameghiniana 33: 463.

Dias-DA-Silva S. 1999. Revisão do conteúdo fossilífero da Formação Sanga do Cabral - Eotriássico do Rio Grande do Sul. Universidade Federal do Rio Grande do Sul, Instituto de Geociências, Dissertação de Mestrado: vii +132 p. +8 plates.

Dias-DA-Silva S \& Schultz CL. 1999a. New procolophonids (Parareptilia, Procolophonoidea) and rhytidosteids (Amphibia, Temnospondyli) of the Triassic of southern Brazil. Ameghiniana 36: 99.

Dias-DA-Silva S \& Schultz CL. 1999b. Bioestratigraphy of hte Permian-Triassic boundary insouthern Brazil. Ameghiniana 36(4) supl.: 10R.

GubiN YM. 1986. New data on the archegosauroids of the East European platform. Paleontological Journal 20: $70-75$.

GubIN YM. 1991. (Permian archegosauroid amphibians of the USSR). Trudy Pal Inst Akad Nauk SSSR 249: $1-138$.

GubIN YM. 1997. Skull morphology of Archegosaurus decheni Goldfuss (Amphibia, Temnospondyli) from the Early Permian of Germany. Alcheringa 21: 103121.

Kitching JW. 1977. The distribution of the Karroo Vertebrate fauna. Bernard Price Institute for Palaeontological Research. Memoir 1: 1-131.

Konzhukova ED. 1955. Platyops stuckenbergi, Trautsch - an archegosauroid labyrinthodont from the lower zone of the Cis-Uralian Upper Permian. Trudy Palaeontological Institute 49: 89-127.

LANGER MC. 2000. The first record of dinocephalians in South America: Late Permian (Rio do Rasto Formation) of the Paraná Basin. N Jb Geol Paläont Abh 215(1): 69-95.

LEE MSY. 1997. A taxonomic revision of pareiasaurian 
reptiles: implications for Permian terrestrial palaeoecology. Modern Geol 21: 231-298.

Milner AR. 1990. The radiations of temnospondyl amphibians. In: TAYLOR PD \& LARWOOD GP. (eds.). Major evolutionary radiations. Systematics Association Special Volume 42: 321-349.

Milner AR. 1993. Amphibian-Grade Tetrapoda. In: Benton M. (Ed.). The fossil record 2. J. Published by Chapman \& Hall, London.: p. 665-679.

Milner AR \& Sequeira SEK. 1997. Slender-snouted Temnospondyls: three radiations or one long lineage? In: Fifth International Congress of VerTEBRATE MoRphology - Bristol, UK . Abstracts. Journal of Morphology 232(3): 295.

Mussa D \& Coimbra AM. 1987. Novas perspectivas de comparação entre as tafofloras permianas (de lenhos) das Bacias do Parnaíba e do Paraná. X Congresso Brasileiro de Paleontologia. Rio de Janeiro. Anais ... 2: 901-922.

PRICE LI. 1948. Um anfíbio labirintodonte da Formação Pedra de Fogo, Estado do Maranhão. Bol Div Geol Min 124: 32p.

Ragonha EW. 1989. Placas dentárias de Dipnoi no Grupo Passa-Dois (P-Tr) da Bacias do Paraná. Apreciações ambientais, climáticas, cronológicas e estratigráficas. XI Congresso Brasileiro de PAleontologia, Curitiba. Anais ... 1: 195-206.
Richter M, Piccoli AEM \& Lima MCS. 1985. Variação morfológica de restos de Paleoniscídeos (Pisces) no Permiano da Bacia do Paraná. MME/DNPM. Coletânea de trabalhos paleontológicos. Paleontologia/Estratigrafia 27: 111-122.

Rubidge BS, Johnson MR, Kitching JW, Smith RMH, Keyser AW \& Groenwald GH. 1995. An introduction to the biozonation of the Beaufort Group. In: RuBidGe BS (Ed.): Biostratigraphy of the Beaufort Group (Karoo Supergroup). S Afr Comm Strat Biostrat Series 1: 1-2.

WeLLES SP. 1993. A review of the lonchorhynchine trematosaurs (Labyrinthodontia), and a description of a new genus and species from the lower Moenkopi Formation of Arizona. PaleoBios 14: 1-24.

Werneburg R \& Schneider J. 1996. The Permian temnospondyl amphibians of India. In: Milner, A. R (ed.) Studies on Carboniferous and Permian vertebrates. Special Papers in Palaeontology 52: 105128.

WÜRDIG-MACIEL NL. 1975. Ichthyodontes e ichthyodorulitos (Pisces) da Formação Estrada Nova e sua aplicação na estratigrafia do Grupo Passa Dois. Pesquisas 5: 7-85+est. 1-14. 